\title{
The Modern Multilateral Bureaucracy: What is the Role of International Administrative Law at International Organizations?
}

\author{
Peter Quayle*
}

\begin{abstract}
What is the role of 'international administrative law' - the law of employment relations - at international organizations? This chapter begins by contrasting the international legal status of States on the one hand, and international organizations on the other, before noting that the bureaucracies of the latter are heir to the traditions and identity of the former. It is then argued that transposing modern bureaucracyideally, meritocratic and impersonal national civil services - to multilateral administration, replaces the 'patrimonial' pressures on modern States with the related risks of 'State sociability' and co-option of international organizations. We then review the several legal bases of international administrative tribunals to discern whether international administrative law takes into account this strain. This chapter draws the conclusion that international administrative law is inherent to the assumption by multilateral administration of the ideals of modern bureaucracy-impartial, efficient and energetic - and so synonymous with the independent existence of international organizations.
\end{abstract}

The functionalist paradigm that underpins the law of international organizations ${ }^{1}$ —namely, that intergovernmental institutions are attributed

* Peter Quayle, Chief Counsel, Corporate at Asian Infrastructure Investment Bank (AIIB) and Visiting Professor of International Organizations Law at Peking University Law School, peterquayle@gmail.com. The contents of this chapter reflect the personal opinion of the individual author and are not the views of АІІв. The author is grateful to Yifeng Chen and Christian Parreno for their comments on an earlier draft.

1 See, for example, ILC, 'Draft Articles on Responsibility of International Organizations' 2011, art 2(a), "international organization' means an organization established by a treaty or other instrument governed by international law and possessing its own international legal 
functions by their member States together with all necessary powers to fulfil such functions - lends itself to a dynamism (or malleability, if you prefer) concerning the competences and controls of these powerful and pervasive international actors. ${ }^{2}$ Tellingly, the limits of the powers of an international organization were most emphatically encountered by the International Court of Justice (ICJ) when ruling what an intergovernmental institution was not: it was not a State, "still less [...] a 'super-State', whatever that expression may mean". ${ }^{3}$

Whilst in Reparation for Injuries (1949), the ICJ determined that an international organization is possessed of an international legal personality, governed by international law, "That is not the same thing as saying that it is a State, which it certainly is not, or that its legal personality and rights and duties are the same as those of a State". 4 The limitation this imposes is underlined by the ICJ in a later advisory opinion, Legality of Nuclear Weapons (1996):

The Court need hardly point out that international organizations are subjects of international law which do not, unlike States, possess a general competence. International organizations are governed by the 'principle of speciality', that is to say, they are invested by the States which create them with powers, the limits of which are a function of the common interests whose promotion those States entrust to them. ${ }^{5}$

Yet, although international law distinguishes between the competences of States and the international organizations they create, they share an institutional identity. The official bureaucracies of States-their national civil service-are the antecedents of the multilateral secretariats of intergovernmental institutions - the international civil service. Therefore, following this introduction, in attempting to answer the question, 'What is the role of international administrative law at international organizations?', this chapter will begin by considering the ideals of modern bureaucracy — of a national civil service (Section 2); before contemplating how transposition of these ideals to

personality"; this chapter uses the terms 'international organization' and 'intergovernmental institution' interchangeably.

2 See, generally, Klabbers 2015, 9 ("Few people would dispute the relevance of international organizations as part of our [normative universe], and yet our understanding of these creatures is very limited").

3 ICJ, Reparations for Injuries, 9.

4 Ibid.

5 ICJ, Legality of Nuclear Weapons, para 25 . 
multilateral administration is accompanied by the sustained strain of State interference upon the neutrality of the international civil service (Section 3). It is then argued that the several legal bases of international administrative tribunals (IATs) reveals the role of international administrative law, and that this correlates to maintaining multilateral administration against co-option by States (Section 4); and by way of conclusion, that as international administrative law ensures the impartiality of international civil servants it secures the independence of international organizations (Section 5).

\section{Modern Bureaucracy}

As Francis Fukuyama discerns, "Human beings [...] are social animals by nature". ${ }^{6}$ This, "natural sociability takes the specific form of altruism toward family (genetic relatives) and friends (individuals with whom one has exchanged favours)". ${ }^{7}$ This is the default pattern of interrelationships- "universal to all cultures and historical period" 8 - to which humanity reverts if strategies to incentivize impersonal behaviors fail. A State based upon inherent human sociability is described by Max Weber as 'patrimonial'; in other words, "the polity is considered a type of personal property of the ruler, and State administration is essentially an extension of the ruler's household". ${ }^{9}$ Weber contrasts this with a modern State, which is impersonal:

[A] citizen's relationship to the ruler does not depend on personal ties but simply on one's status as citizen. State administration does not consist of the ruler's family and friends; rather, recruitment to administrative positions is based on impersonal criteria such as merit, education or technical knowledge. ${ }^{10}$

This impersonal administration —-modern bureaucracy—whilst attained in ancient China, was not there merged with an accountable, rule of law based,

\begin{tabular}{ll}
\hline 6 & Fukuyama 2014, 8. \\
7 & Ibid. \\
8 & Ibid. \\
9 & Ibid, 10. \\
10 & Ibid.
\end{tabular}


modern State." Instead, contemporary modern bureaucracy was achieved in nineteenth century Britain as a consequence of the Northcote-Trevelyan Report of 1854-a parliamentary report calling for an end to patronage appointments and for examination to be the exclusive basis for entrance into the British civil service. A Civil Service Commission was established in 1855 to oversee this process of competitive recruitment. ${ }^{12} \mathrm{~A}$ similar effect was achieved in the United States (US) later in the century with the passing of the Pendleton Act in $1883 .{ }^{13}$ In both the United Kingdom and the US, a steadily professionalizing civil service "and the selection of bureaucrats based on merit and technical competence rather than patronage"14 was synonymous with the potency of the modern State.

Weber's criteria for a modern bureaucracy is instructive, including: that bureaucrats "are organized into a clearly defined hierarchy of offices"; "candidates are selected on the basis of technical qualifications"; "the office is treated as the sole occupation of the incumbent"; "the office constitutes a career"; and "officials are subject to strict discipline and control". ${ }^{15}$ Of course, in practice, the ideal national civil service is far from ubiquitous. Nevertheless, it is these ideals of modern bureaucracy that are transposed to multilateral administration. In the process, the tendency to revert to a patrimonial polity is matched by the risks of State co-option of an international organization. This is not to say that the member States of international organizations do not possess a legitimate role in the governance of intergovernmental institutions. But that this role is to be confined to the constitutional exercise of influence through formal decision-making organs.

\section{$3 \quad$ Multilateral Administration}

Dag Hammarskjöld was the lauded, second Secretary-General of the United Nations. ${ }^{16}$ As Guy Fiti Sinclair notes, "For many in the UN and outside it, Hammarskjöld was the epitome of the impartial, non-partisan international civil

\footnotetext{
11 Ibid, 370-371.

12 Ibid, 126-134.

13 Ibid, 149-164.

14 Ibid, 59.

15 Ibid, 562, endnote 4, lower-case added.

16 Sinclair 2015, 748 ("While serving in that capacity during the crucial years of 1953-1961, at the height of the Cold War and decolonization and perhaps the most formative period of UN history, Hammarskjöld was intimately involved in the formulation of several legal innovations that have since become staples of UN activity, including preventive diplomacy and peacekeeping").
} 
servant". ${ }^{17}$ In publicly defending the embattled international civil service, Hammarskjöld draws attention to the traditions of the great national civil services:

In the United Kingdom, as in certain other European countries, a system of patronage, political or personal, had been gradually replaced in the course of the nineteenth century by the principle of a permanent civil service based on efficiency and competence and owing allegiance only to the State which it served.18

It was not a foregone conclusion that these attributes would be conveyed from the national to the international civil service. In the same way that an impersonal national civil service was once a novelty, Stephen Schwebel notes, "The concept of a secretariat which, as the [UN] Charter prescribes, shall be of 'exclusively international character' is relatively new". ${ }^{19}$ Indeed, this defining characteristic is unmentioned in the Covenant of the League of Nations. A permanent Secretariat is established with its seat in Geneva ${ }^{20}$ and, "The secretaries and staff of the Secretariat shall be appointed by the Secretary-General with the approval of the Council". ${ }^{21}$ But, the profile of the League's Secretariat is otherwise only governed by Article 7 of the Covenant whichcommendably—requires appointments "open equally to men and women". As Hammarskjöld recounts:

In the earliest proposals for the Secretariat of the League, it was apparently taken for granted that there could not be a truly international secretariat but that there would have to be nine national secretaries, each assisted by a national staff and performing, in turn, the duties of Secretary to the Council, under the supervision of the Secretary-General. This plan $[\ldots]$ was in keeping with the precedents set by the various international bureau established before the war which were staffed by officials seconded by $[\mathrm{m}]$ ember countries on a temporary basis. ${ }^{22}$

This recognizes that the most natural organizational tendency on the level of international cooperation resembles the same persistent pattern at the

\footnotetext{
17 Ibid, 755; importantly, Sinclair essays a critique of this reputation.

18 Hammarskjöld 1961, 331.

19 Schwebel 1953, 71, citing art 100(2) of the UN Charter.

$20 \quad$ League of Nations Covenant, arts 2 and 6.

21 Ibid, art 6.

22 Hammarskjöld 1961, 330; and League of Nations Covenant, art 4; the Leagues' Council was to comprise nine member States.
} 
national level —namely, patronage-based, not impersonal, bureaucracy; albeit, that the preferment of family and friends is replaced with State co-option of international organizations and the sponsorship of same-State-national staff accordingly. Henceforth, this chapter terms this irrepressible tendency, 'State sociability'. At best, "The Secretariat would be nothing more and nothing less than a permanent conference of representatives of the members of the League", as the League's first Secretary-General, former British civil servant, Sir Eric Drummond feared. At worst, the League and subsequent international organizations would resemble the four-way zonal administration of post-war Berlin. In this scenario, intergovernmental institutions would be indistinguishable from their member States.

But, summoning the example of disinterested modern bureaucracy, Drummond was instead a proponent "of a truly international civil service-officials who would be solely the servants of the League and in no way representative of or responsible to the $[\mathrm{g}]$ overnments of the countries of which they were nationals". ${ }^{23}$ The League's Council endorsed this approach in 1920 by adopting the British delegation's 'Balfour Report'.24 This states, "the members of the Secretariat once appointed are no longer the servants of the country of which they are citizens, but become for the time being the servants only of the League of Nations [...] The members of the staff carry out [...] not national but international duties". ${ }^{25}$ This assumed the force of international administrative law with the League's adoption of Staff Regulations, founding "two of the essential principles of an international civil service: (i) its international composition and (ii) its international responsibilities". ${ }^{26}$ With the demise of the League, this became the basis for Article 100 of the UN Charter, which states:

1. In the performance of their duties the Secretary-General and the staff shall not seek or receive instructions from any government or from any other authority external to the [UN]. They shall refrain from any action which might reflect on their position as international officials responsible only to the [UN].

2. Each [member State] of the United Nations undertakes to respect the exclusively international character of the responsibilities of the Secretary-General and the staff and not to seek to influence them in the discharge of their responsibilities.

\footnotetext{
23 Ibid, 229.

24 Drummond 1931, 228 (indeed, "the principles underlying the organization of the Secretariat of the League are largely those on which the British Civil Service has been developed").

26 Hammarskjöld 1961, 76 .
} 
In this way, Article 100 secures the undivided duty of loyalty of the international civil service. ${ }^{27}$ So much so that it preempts the inevitable tension between national and multilateral allegiances - "in such an eventuality, the international obligations of the staff member would prevail". ${ }^{28}$ Article 101(3) of the UN Charter likewise endeavours to establish the international civil service on the basis of impersonal appointment criteria:

The paramount consideration in the employment of the staff and in the determination of the conditions of service shall be the necessity of securing the highest standards of efficiency, competence, and integrity. Due regard shall be paid to the importance of recruiting the staff on as wide a geographical basis as possible.

The 'necessity of securing' these highest standards highlights how efficiency, competence and integrity must be institutionalized, in counterbalance to State sociability. In light of this 'paramount condition', the 'due regard' paid to the multinational composition of the bureaucracy may be understood to weigh against the co-option of international organizations through the overrepresentation of any one State's nationals.

Lastly, three other clauses of the UN Charter combine to constitute the ideals of modern bureaucracy: Firstly, the Secretary-General "shall be the chief administrative officer of the [UN]"; second, "[t]he staff shall be appointed by the Secretary-General under regulations established by the General Assembly"; and third "...officials of the [United Nations] shall [...] enjoy such privileges and immunities as are necessary for the independent exercise of their functions in connection with the [UN]". ${ }^{29}$ This results, Schwebel notes, in the "exclusively international responsibilities of the Secretariat" being "rooted in the exclusively international process of appointment of its members". ${ }^{30}$ They are also the foundation of the organizational hierarchy and "strict discipline and control" that Weber's modern bureaucracy contemplates.

It may be thought that co-option of an international organization by a State through its same-nationality staff is fanciful. Yet, Hammarskjöld catalogues, "the interest of $[\ldots]$ governments in placing certain nationals and in barring the employment of others" at the UN. ${ }^{31}$ Moreover, "various authorities of the United States Government, host to the United Nation's Headquarters", in the

\footnotetext{
27 See Quayle, Legal Advisors 2017, 259-261.

28 Schwebel 1953, 99.

29 UN Charter, arts 97, 101 and 105(2), respectively.

$30 \quad$ Schwebel 1953, 79.

$31 \quad$ Hammarskjöld 1961, 339.
} 
early 1950s, "conducted a series of highly publicized investigations of the loyalty of its nationals in the Secretariat". ${ }^{22}$ There is also, "[a] risk of national pressure on the international official [...] introduced, in a somewhat more subtle way, by the terms and duration of [their] appointment". ${ }^{33}$ The SecretaryGeneral has in mind the practice of secondment to international organizations from national civil services, in which the now international official struggles to disregard their State allegiance and assume an impartial identity; and shortterm employment contracts which impinge upon the independence of international civil servants as they bow to political influences for fear of imminent non-renewal of their appointment. ${ }^{34}$ (So offending Weber's principle, that the office constitutes a career.)

These State pressures are neither new, nor confined, to the UN, and all international organizations attempt to absorb them. In this way, at the outset of the League of Nations it was found politic to establish sufficient Deputy- and Under-Secretary-General roles, so that together with the Secretary-General appointment itself, the nationals of all five Allied Great Powers were ensured representation. ${ }^{35}$ Although, "[t]he Under-Secretaries-General created with some the impression of national representatives rather than international officials", ${ }^{36}$ this compromise safeguarded the underlying impartiality of the rank-and-file international civil service. In other words, as Schwebel urges, the "official policy and dominant practice conformed to the concept of the Secretariat as being exclusively international in its responsibilities". ${ }^{37}$ Set against this principle, "exceptions which derogated from the rule"38 are isolated and pragmatic concessions to State sociability.

Deflecting the intrusions of State sociability through the appointment of quasi-representative officials in this way is intrinsic to all international organizations. As Jacob Katz Cogan demonstrates, "informal agreements allocating positions of authority and decision making pervade international

32 Ibid, 340; this is a passing reference to McCarthyite allegations of subversive activities by US national staff of the UN, leading to their dismissal by the Secretary-General and fraught examination of the extent of obligations owed a headquarters State, see generally, Schwebel 1953, 83-115 and 115, "The question arises whether the members of a totalitarian party, subject to party discipline, can be reasonably deemed to lack the requisite integrity for honouring the injunction of Article 100 'not to seek or receive instructions [...] from any other authority external to the Organization"').

33 Ibid, 341.

34 Ibid.

35 Drummond 1931, 229; namely France, Great Britain, Italy, Japan and United States.

36 Schwebel 1953, 73 .

37 Ibid.

38 Ibid. 
organizations".39 But, notably, as with the five senior members of the League's Secretariat,

These informal agreements largely take account of, and reallocate authority to match, the differences in power and interests that pervade the international system when those differences cannot be acknowledged formally. ${ }^{40}$

The most widely-known examples of such informal agreement are that the World Bank is always led by a US national and the International Monetary Fund by a European. ${ }^{41}$ Taken together, this also exemplifies how "the designation of top posts cannot be seen in isolation - they are often part of a package deal". ${ }^{42}$ Whilst, a functional justification is sometimes offered-"appointing governmentally approved staff will be likely to promote the international confidence which the Secretariat must enjoy" - this seems self-defeating, if "the greater the confidence shown by a $[\mathrm{g}]$ overnment in its nationals appointed to the Secretariat, the more will the objectivity of such nationals be distrusted by other $[\mathrm{m}]$ ember States". ${ }^{43}$

A more effective constraint is afforded by, on the one hand, these 'quasirepresentational' positions being appointed, seldom on the basis of the distortion of impersonal criteria, but as an uninhibited governance decision-if necessary, by formal voting - by a membership organ of an international organization. ${ }^{44}$ On the other hand, these appointees are then-somewhat surprisingly—subsumed into the international civil service. For example, the Administrative Tribunal of the International Labour Organization (ILOAT) determined that the Director-General of the Organization for the Prohibition of Chemical Weapons (OPWC), appointed by the Conference of the States Parties

39 Cogan 2009, 211.

40 Ibid.

41 Cogan 2009, 247; IBRD Country Voting Table (The United States subscribes for $16.76 \%$ of the World Bank's capitalization); and IMF Executive Directors and Voting Power (The voting power of the United States is $16.51 \%$, however, the total voting power of Directors with European States in their constituencies is $32.22 \%$ ).

42 Cogan 2009, 228.

43 Schwebel 1953, 102, summarizing the equivalent considerations of State vetting of international organization staff.

44 For example, UN Charter, art 97, second sentence, "The Secretary-General shall be appointed by the General Assembly upon the recommendation of the Security Council". 
of the OPCW, is "the foremost 'official' of the Organization", 45 and thereby possesses "the status of an international civil servant". 46

The transposition of the ideals of modern bureaucracy to multilateral administration is clearly subject to the sustained strain of potential State co-option. State sociability is partially absorbed by the extensive appointment of quasi-representational national officials. Considering the governance basis of these appointments and sublimation to the standards of the international civil service, this is presented as a tolerable derogation from the ideals of modern bureaucracy that ought to otherwise rule multilateral administration. In studying the several legal bases of IATs, which function to adjudicate the employment-related disputes of international civil servants, may we discern a role for international administrative law in managing the stresses of State sociability upon international organizations?

Since the advent of the League of Nations, IATs have been inherent to an international civil service governed by international administrative law. ${ }^{47}$ As Santiago Villapando observes, "The law of the international civil service is therefore an essential feature of the contemporary phenomenon of international organizations". ${ }^{48}$ Consequently, a study of the legal bases of IATs should afford an assessment of the role of international administrative law-and allow us to discern the extent to which this role involves managing the tendencies of State sociability to which the international civil service is inevitably subject. IATs have four prominent legal bases. Firstly, and most immediately, the basis afforded by the statement of jurisdiction in the statues of IATs; second, is the basis of limited review of discretionary decisions established by the case law of IATs; third, the influential contingency identified by the European Court of Human Rights (ECtHR) in considering the extent to which IATs should satisfy the right to a hearing afforded by the European Convention on Human Rights (ECHR); and fourth, the basis articulated by the ICJ, when called upon to sustain the competence of international organizations to establish IATs at all. We

\footnotetext{
45 ILOAT, Judgment No 2232, para 7.

46 Ibid, para 8.

47 See generally, Villapando, International Administrative Tribunals 2016, 1085 ("These tribunals are part of the internal systems of administration of justice that international organizations have put into place to settle employment disputes, which would otherwise fall under no jurisdiction").

48 Villapando, International Civil Service Law 2016, 1070.
} 
shall consider each of these legal bases in turn, in light of what they may convey about the role of international administrative law, in the context of modern multilateral administration.

\subsection{Statutes of International Administrative Tribunals}

The statutes of IATs - adopted by the governance organs of international organizations ${ }^{49}$ - establish their legal basis by reference to a jurisdiction entirely bounded by the terms of appointment (also referred to as the contract of employment) to the staff of an intergovernmental institution. In this way, the jurisdiction of the ILOAT is innocuous:

The Tribunal shall be competent to hear complaints alleging nonobservance, in substance or in form, of the terms of appointment of officials of the International Labour Office, and of such provisions of the Staff Regulations as are applicable to the case. ${ }^{50}$

The jurisdiction of the World Bank Administrative Tribunal (WBAT) is similar:

The Tribunal shall hear and pass judgment upon any application by which a member of the staff of the Bank Group alleges non-observance of the contract of employment or terms of appointment of such staff member. The words 'contract of employment' and 'terms of appointment' include all pertinent regulations and rules in force at the time of alleged non-observance including the provisions of the Staff Retirement Plan. ${ }^{51}$

The comparable provision of the statute of the UN Dispute Tribunal (UNDT) establishes that the UNDT is competent to,

$[\mathrm{H}]$ ear and pass judgment on an [...] appeal [of] an administrative decision that is alleged to be in non-compliance with the terms of appointment or the contract of employment. The terms 'contract' and 'terms of appointment' include all pertinent regulations and rules and all relevant administrative issuances in force at the time of alleged non-compliance. ${ }^{52}$

49 See, Preambles, ILOAT, WBAT and UndT Statutes: the ILOAT is established by the International Labour Conference of the International Labour Organization; the WвAт by the Board of Governors of the World Bank; the UNDT by the UN General Assembly.

50 ILOAT Statute, art II (1).

$5^{1} \quad$ WBAT Statute, art II (1).

52 UNDT Statute, arts 1 and 2(1). 
Noticeably, none of the statutes of the three major IATs attribute a legal basis to international administrative law, other than the contracts of employment or terms of appointment of international organizations. Nor is the law governing this relationship identified by these statutes. The functional rationale of IATs is not obvious. Nothing suggests that the approach by IATs to hearing complaints and passing judgment should be anything other than wholly self-contained, without reference to any exterior legal principles. In this way, the role of international administrative law is left unstated and uncertain.

\subsection{Deference to Discretionary Decision-Making}

Instead, the application of international administrative law by IATs is dominated by a doctrine that is unarticulated by the statutes of IATs. Namely, the limited review of discretionary power. The extent to which the "relevant administrative issuances" of international organizations are compendious-regulating almost every imaginable aspect of employment—engages a broad range of alternative outcomes. From the decision to appoint an international official through to the decision to terminate their employment, the exercise of discretion by the employing international organization causes IATs to limit the scope of their judicial review. IATs reiterate this approach ad infinitum—for example:

The [ILOAT's] case law has it that a staff appointment by an international organization is a decision that lies within the discretion of its executive head. Such a decision is subject to only limited review and may be set aside only if it was taken without authority or in breach of a rule of form or of procedure, or if it was based on a mistake of fact or of law, or if some material fact was overlooked, or if there was abuse of authority, or if a clearly wrong conclusion was drawn from the evidence. ${ }^{53}$

This approach is emulated by every other IAT. ${ }^{54}$ In other words, in order not to be set aside, a discretionary decision must be undertaken by: (i) a competent

53 ILOAT, Judgment No 3652 , para 7.

54 For example, wвAт, Jassal, para 37, "[T] he Tribunal is charged with determining whether the Bank's decision was the product of bias, prejudice, arbitrariness, manifest unreasonableness, or unfair or improper procedure. Thus, if the Bank's conclusion regarding the [a]pplicant's qualifications for selection [...] altogether lacks support in factual evidence or reasonable inference, that conclusion must be found to be an abuse of discretion"; and UNAT, Abassi, para 24, "The Secretary-General has a broad discretion in making decisions regarding promotions and appointments. In reviewing such decisions, it is not the role of the UNDT or the Appeals Tribunal to substitute its own decision for that of the SecretaryGeneral regarding the outcome of the selection process". 
authority; (ii) in accordance with the accompanying procedure established by the international organization; and (iii) demonstrate sufficient rigour and reasonableness so as not to be susceptible to mistaken understandings, oversights, prejudices and erroneous conclusions. However, in the sense of the resultant role of international administrative law at international organizations, this results in three discernable institutional features.

Firstly, international administrative law acts to constrain a decision-maker, rather than to adjudicate a contractual bargain. Albeit, as the WвAт states, "Discretionary power is not absolute power", 55 it is apparent that international administrative law is predicated upon a power imbalance and the "strict discipline and control" and "clearly defined hierarchy" contemplated by Weber. This is a legacy of the Commission of Jurists appointed by the Council of the League of Nations to address the first appeal by an official of the Secretariat against termination of their employment. The Commission concluded that " $[r]$ elations connected with public employment are always governed by the exigencies of the public interest, to which the private and personal interests of the officials must necessarily give way". ${ }^{6}$ This approach privileges the discretionary power of public administration and consequently international organizations. (Although the domestic analogy is imperfect "since municipal systems have different conceptions of how their own national civil service relationship is to be construed". ${ }^{57}$ This is not then a law intended to maximize human resources or ensure managerial excellence-it is the law of restraint of egregious intergovernmental arbitrariness.

Second, inherent in even this standard of limited review is longstanding uncertainties. Neither the test of reasonableness, the implications of nonadherence to procedure, nor the consequences of a decision being set aside have been pronounced upon with the same uniformity as the limited scope of review itself. Instead, the combination of specific facts and contextualizing review lends itself to persistent unforeseeability: every issue being triable and the continual retrying of issues. ${ }^{58}$

\footnotetext{
$55 \quad$ WBAT, de Merode, para 45.

56 Schwebel 1953, 74, citing the Commission's report.

57 Villapando, International Civil Service Law 2016, 1073.

$5^{8}$ The one-line summaries from the ILOAT's Case-law Database afford a flavour. The following are the most recent five, from the 129th Session, 2020, with the respondent international organizations in parenthesis: "The complainant impugns the decision whereby the Director-General of the ITE R Organization dismissed [them]" (ITER Organization); "After the delivery of Judgment 4006, the complainant re-submitted to the new Registrar of the
} 
Third, the preponderance of IATs and the density of most judgments, results in international administrative law being unrevealed to the average international official. With good reason, international administrative law is said to be, "among the least-known dimensions of the phenomenon of international organizations". ${ }^{9}$ Taken together, these features are at best unsatisfactory, and at worst, troubling if-as a UN Justice System Redesign Report lately finds"A large part of the current management culture in the [UN] exists because it is not underpinned by accountability. Accountability can be guaranteed only by an independent, professional and efficient internal justice system". ${ }^{60}$

\subsection{The Right to a Hearing by a Tribunal}

Since the League of Nations and the advent of multilateral administration, IATs were considered to be mostly pragmatic requirements of international organizations. On the one hand, "The League Administration was not unaware that a mechanism which was either arbitrary or harsh in its personnel policies could not expect to attract the devotion and energies of qualified officials". 61 On the other hand, "International organizations are generally granted immunity from municipal jurisdiction, which implies that their employees are, in principle, barred from having recourse to national tribunals (both those of the host country and their own state of nationality)".62 It was not until the judgment of the ECtHR in Waite and Kennedy $v$ Germany (1999) that an IAT was considered to be a contingency of the jurisdictional immunity of international organizations.

ICC a harassment grievance on the part of the former Registrar. [They] filed [their] complaint directly with the Tribunal, considering that [they] did not receive a final decision on [their] grievance within the prescribed time limit" (International Criminal Court); "The complainants, former officials of the World Food Programme whose employment was terminated as a result of the abolition of their posts, allege that they performed functions of a higher level than those of the posts they occupied, and claim compensation as well as reinstatement". (Food and Agriculture Organization); “The complainant, a former EPO employee subjected to a 'house ban', seeks to impugn the decision to reject [their] requests for review" (European Patent Office); and "The complainant, who was suspended and revoked for having behaved inappropriately, challenges the delay in the appeal proceedings" (INTERPOL).

59 Villapando, International Civil Service Law 2016, 1083.

6o UN Justice System Redesign Report 2016, para 13.

61 Schwebel 1953, 75.

62 Villapando, International Administrative Tribunals 2016, 1085. 
The applicants, former contractors - who allege that they were de facto employees - of the European Space Agency (ESA), contend that the preclusion of jurisdiction of the German labour courts where they worked, over their claims for unfair dismissal, flout their rights under Article 6(1) of the European Convention on Human Rights (ECHR) to a fair hearing before a tribunal. Importantly, the ECtHR is untroubled by jurisdictional immunity itself: "[T]he Court points out that the attribution of privileges and immunities to international organizations is an essential means of ensuring the proper functioning of such organizations free from unilateral interference by individual governments". 63 Thus, under the jurisprudence of the ECtHR, jurisdictional immunity pursues, what is known as, a 'legitimate objective'-so, the restriction on the Convention is permissible, but it must however be proportionate. ${ }^{64}$

Is barring employees of international organizations from the labour courts of States that are both members of an intergovernmental institution (the ESA, for example), and adherents to the ECHR, proportionate? The Court is clear that despite the long-established practice of jurisdictional immunity, "States were [not] thereby absolved from their responsibility under the Convention".65 However, in testing the proportionality of this jurisdictional immunity, the ECtHR is interested in what arrangements the international organization has in place of national jurisdiction:

For the Court, a material factor in determining whether granting ESA immunity from German jurisdiction is permissible under the Convention is whether the applicants had available to them reasonable alternative means to protect effectively their rights under the Convention. ${ }^{66}$

From this judgment arose an apprehension that the jurisdictional immunity of international organizations was contingent upon the availability of alternative judicial forums - in the realm of employment-related disputes this demands an IAT of sufficiently judicial character to act as a reasonable alternative to a national labour court. ${ }^{67}$ As August Reinisch identifies, this aligns with expanded expectations of a right of access to justice:

\footnotetext{
63 ECtHR, Waite and Kennedy, para 63.

64 Ibid, para 59.

65 Ibid, para 67.

66 Ibid, para 68.

67 See, generally, Reinisch 2008.
} 
[A]lthough it did not make the availability of an alternative forum a strict prerequisite for immunity but only regarded it a 'material factor', this 'conditionality' for granting immunity to an international organization has fallen on fertile ground in the subsequent case law of various national courts in Europe. ${ }^{68}$

But, afforded the opportunity to confirm this contingent legal basis of IATsin Mothers of Srebrenica $v$ The Netherlands (2012) - the ECtHR refuses to endorse this conclusion: "It does not follow, however, that in the absence of an alternative remedy the recognition of immunity is ipso facto constitutive of a violation of the right of access to a court".69 In other words, the contingent legal basis of IATs and the related role of international administrative law suggested by Waite and Kennedy, "cannot be interpreted in such absolute terms".70

\subsection{Treaty Basis of International Administrative Tribunals}

If the legal bases attributable to IATs by their statutes, the convention of deference to the discretionary decision-making by international organizations and the right to a hearing before a tribunal, result in an inconclusive role for international administrative law, then the approach of the ICJ in Effect of Awards of Compensation (1954) is all the more compelling. The contentious role of the UN's administrative tribunal in reviewing, and intermittently revoking, the alleged subversive activity related dismissals in the early 1950s, led to a challenge to "[t]he legal power of the [UN] General Assembly to establish a tribunal competent to render judgments binding on the United Nations".71 The ICJ begins by identifying the familiar pragmatic predicate of IATs; namely, that "[i]t was inevitable that there would be disputes between the [UN] and staff members as to their rights and duties" and "Article 105 [of the UN Charter] secures for the United Nations jurisdictional immunities in national courts".72

The next sentence of the ICJ's Advisory Opinion could be mistaken for the gravamen of the judgment. Although no provision of the UN Charter expressly establishes an IAT,

It would, in the opinion of the Court, hardly be consistent with the expressed aim of the Charter to promote freedom and justice for individu-

\footnotetext{
$68 \quad$ Ibid, 292.

69 ECtHR, Mothers of Srebrenica, para 164.

70 Ibid.

71 ICJ, Effect of Awards, 13.

72 Ibid, 14.
} 
als and with the constant preoccupation of the United Nations [...] to promote this aim that it should afford no judicial or arbitral remedy to its own staff for the settlement of any disputes which may arise between it and them. ${ }^{73}$

But instead, this is in fact an aid to the Court's finding - it identifies the best methodology to settle the UN's employment-related disputes, namely, judicial or arbitral remedy. Rather, the ICJ holds that the legitimate legal basis for IATS is derived from the exceptional status of the international civil service:

In these circumstances, the Court finds that the power to establish a tribunal, to do justice as between the [UN] and the staff members, was essential to ensure the efficient working of the Secretariat, and to give effect to the paramount consideration of securing the highest standards of efficiency, competence and integrity. Capacity to do this arises by necessary intendment out of the Charter. ${ }^{74}$

In other words, the legal basis of IATs is that they are necessary to multilateral administration ensuring the embodiment of the ideals of modern bureaucracy. As Hammarskjöld warns, "The conception of an independent international civil service, although reasonably clear in the Charter provisions, was almost continuously subjected to stress in the history of the [UN]". ${ }^{75}$ The attendant role of international administrative law, necessarily intended by the UN Charter itself, is thereby to secure the efficiency, competence and integrity of an international civil service continually strained by sustained and inevitable State pressures upon its impartiality.

The "default mode of human sociability" is the preference for family and friends, not strangers and foreigners. ${ }^{76}$ At the State level, this tendency lends itself to patrimonial polities and a State that is the extension of the personal

\footnotetext{
73 Ibid.

74 Ibid.

75 Hammarskjöld 1961, 338; see also Sinclair 2015, 761 (strikingly, "An aspect of Hammarskjöld's expertise that has received almost no systematic scholarly treatment, for example, is his approach to public administration").

76 Fukuyama 2014, 208.
} 
property of the ruler. The modern bureaucracy-impersonal, technically qualified, competitively recruited, national civil services-is inherent to a potent, rule of law based and accountable, modern State, resistant to these profound pressures. The ideals of modern bureaucracy are the institutional inspiration of multilateral administration. In the course of this transposition, patrimonial pressures are replaced by the strain of State sociability and co-option. In other words, the exertion of inevitable influence by States on the staff of international organizations. Intergovernmental institutions attempt to absorb this strain by acceding to quasi-representative high-level appointments, as a derogation from the rule of impersonality of the rank-and-file international civil service. International administrative law is intrinsic to securing the exceptional status of international officials, namely their independence. Notably, the ICJ judges this impartiality of the international civil service so fundamental as to be correlated with the independence of an international organization itself.

The full caption of Reparation for Injuries reminds us that the ICJ's determination that international organizations possess international legal personality is in the aftermath of injuries (including fatalities), suffered by international civil servants in the service of the UN. ${ }^{77}$ In 1948 , the assassination in Jerusalem of Count Folke Bernadotte and other members of the UN Mission to Palestine, raised, "with greater urgency than ever, the question of the arrangements to be made by the United Nations with a view to ensuring to its agents the fullest measure of protection in the future and ensuring that reparation be made for the injuries suffered". ${ }^{78}$ The convention of relying upon the same-nationalityState to represent and protect persons on the international legal plane against the actions of other States is incompatible with the independence of international officials. Consequently, the ICJ concludes that, to enable the independent action of an international organization, the independence of international officials must be ensured-and vice versa. ${ }^{79}$

Fukuyama terms backsliding by modern States, 'repatrimonialisation', and identifies it as a mechanism of political decay - the rotten, re-personalized State becomes incapable of governing effectively. ${ }^{80}$ This "leads either to slowly increasing levels of corruption, with correspondingly lower levels of government effectiveness, or to violent populist reactions to perceived elite manipulation".81 Given the strength of the related strains of State sociability,

77 See Quayle, Treaties of a Particular Type 2016, 871-873.

78 ICJ, Reparation for Injuries, 9, citing the UN General Assembly resolution referring the request for an Advisory Opinion to the ICJ.

79 Ibid, 13.

8 F Fukuyam 2014, 35 .

81 Ibid, 28. 
there is no reason to discount the risk of 'repatrimonialisation' of international organizations. Whilst, "a spirit of international loyalty among public servants can be maintained in practice", Drummond's experience of leading the League of Nations Secretariat was "also that maintenance of such a spirit is an essential factor in the activity of an international service, since this alone can ensure to it that confidence without which it cannot function as it ought". 82 If the political decay of an international organization resembled that of a modern State, the compromised international civil service would lead to dwindling governance effectiveness and the de-legitimizing of the intergovernmental institution. In other words, international organizations are only international organizations because of the independence of the international civil service. The resulting role of international administrative law is surely to maintain this exclusively international loyalty, indispensable to modern multilateral administration.

\section{Reference List}

Abassi $v$ Secretary-General of the United Nations (Judgment No 2011-UNAT-110) [2011] UNAT.

Charter of the United Nations and Statute of the International Court of Justice (signed 26 June 1945, entered into force 24 October 1945).

Cogan JK, 'Representation and Power in International Organization: The Operational Constitution and its Critics' (2009) 103 The American Journal of International Law 209 .

The Covenant of the League of Nations (1919) <https://avalon.law.yale.edu/2oth _century/leagcov.asp $>$ accessed 1 May 2020.

Drummond E, 'The Secretariat of the League of Nations-Paper read before the Institute of Public Administration, 19 March 1931'.

Effect of Awards of Compensation Made by the United Nations Administrative Tribunal (Advisory Opinion) [1954] ICJ Rep 47.

European Convention for the Protection of Human Rights and Fundamental Freedoms (adopted 4 November 1950, entered into force 3 September 1953) 213 UNTS 221. Fukuyama F, Political Order and Political Decay (Profile Books 2014).

Hammarskjöld D, 'The International Civil Servant in Law and Fact-Lecture delivered to Congregation at Oxford University, 30 May 1961' <https://www.un.org/depts/dhl/ dag/docs/internationalcivilservant.pdf $>$ accessed 1 May 2020.

82 Schwebel 1953, 6, quoting deliberations of a group of League officials, chaired by Sir Eric Drummond. 
International Bank for Reconstruction and Development (IBRD), Country Voting

Table, April 2020, <http://pubdocs.worldbank.org/en/795101541106471736/IBRD CountryVotingTable.pdf $>$ accessed 1 May 2020.

International Law Commission, 'Draft Articles on Responsibility of International Organizations, with Commentaries' (2011) UN Doc A/66/10.

International Monetary Fund (IMF), IMF Executive Directors and Voting Power $<$ https://www.imf.org/external/np/sec/memdir/eds.aspx\#2> accessed 1 May 2020.

Jassal $v$ International Bank for Reconstruction and Development (Decision No 100) [1991] WBAT.

JM в $v$ Organisation for the Prohibition of Chemical Weapons (Judgment No 2232) [2003] ILOAT.

Klabbers J, 'The EJIL Foreword: The Transformation of International Organizations Law' (2015) 26 European Journal of International Law 9.

Legality of the Threat or Use by a State of Nuclear Weapons (Advisory Opinion) [1996] ICJ Rep. 66.

$P($ Nos 1 and 2) $v$ Food and Agricultural Organization (Judgment No 3652) [2016] ILOAT.

Quayle P, 'Legal Advisers and International Organizations: The Convergence of Interior and Exterior Legal Obligations' in Zidar A and Gauci J-P (eds), The Role of International Legal Advisers in International Law (Brill Nijhoff 2017).

Quayle P, ‘Treaties of a Particular Type: The ICJ's Interpretative Approach to the Constituent Instruments of International Organizations' (2016) 29 Leiden Journal of International Law 853.

Reinisch A, 'The Immunity of International Organizations and the Jurisdiction of Their Administrative Tribunals' (2008) 7 Chinese Journal of International Law 285.

Reparation for Injuries Suffered in the Service of the United Nations (Advisory Opinion) [1949] ICJ Rep 174.

Schwebel S, 'The International Character of the Secretariat of the United Nations' (1953) 30 Brit YB Int'l L 71.

Sinclair GF, 'The International Civil Servant in Theory and Practice: Law, Morality, and Expertise' (2015) 26 European Journal of International Law 747.

Statute of the Administrative Tribunal of the International Labour Organization(ILOAT) <https://www.ilo.org/tribunal/about-us/WCMS_249194/lang--en/index.htm> accessed 1 May 2020.

Statute of the United Nations Dispute Tribunal (UNDT) < https://www.un.org/en/inter naljustice/pdfs/UNDT_Statute.pdf $>$ accessed 1 May 2020.

Statute of the World Bank Administrative Tribunal (WBAT) <https://tribunal.world bank.org/statute> accessed 1 May 2020.

Stichting Mothers of Srebrenica and Others $v$ the Netherlands App No 65542/12 (ECtHR, 8 October 2012). 
United Nations General Assembly, 'Report of the Redesign Panel of the United Nations System of Administration of Justice' (28 July 2006) UN Doc A/61/205.

Villapando S, 'The Law of the International Civil Service' in Cogan JK, Hurd I and Johnstone I (eds), The Oxford Handbook of International Organizations (Ou P 2016).

Villapando S, 'International Administrative Tribunals' in Cogan JK, Hurd I and Johnstone I (eds), The Oxford Handbook of International Organizations (OUP 2016).

Waite and Kennedy v Germany App No 26083/94 (ECtHR, 18 February 1999). 